\title{
Blood Cell Morphology and Plasma Biochemistry in Russian Tortoises
} (Agrionemys horsfieldi)

\section{Z. KNOTKOVÁ ${ }^{1}$, J. DOUBEK ${ }^{1}$, Z. KNOTEK ${ }^{2}$, P. HÁJKOVÁ $^{2}$}

${ }^{1}$ Department of Physiology, ${ }^{2}$ Small Animal Clinic,

Faculty of Veterinary Medicine, University of Veterinary and Pharmaceutical Sciences Brno, Czech Republic

Received December 14, 2001

Accepted June 19, 2002

\section{Abstract}

Knotková Z.,J. Doubek, Z. Knotek, P. Hájková: Blood Cell Morphology and Plasma Biochemistry in Russian Tortoises (Agrionemys horsfieldi). Acta Vet. Brno 2002, 71: 191-198.

Morphological characteristics of peripheral blood cells and plasma biochemistry profile were examined in twenty clinically healthy Russian tortoises (Agrionemys horsfieldi). Blood samples were collected from dorsal coccygeal vein. The Pappenheim staining method was used as the basal method for the classification of the blood cells. For enriching staining panel the commercial kits Rapidiff®, Lysocolor $₫$, Lymphocolor ${ }^{\circledR}$, Monocolor $₫$, Granulocolor $®$ and Neutrocolor ${ }^{\circledR}$ were used. Ten different types of blood cells were determined: erythrocytes, thrombocytes, lymphocytes, monocytes, type-I cells (heterophils), type-II cells (eosinophils), type-III cells (azurophils), type-IV cells (basophils), type-Ia cells (toxic heterophils) and type$\mathrm{V}$ cells (polychromatophil erythrocytes). Stained with Lysocolor ${ }^{\circledR}$, the positive reaction emerged in type-IV cells and less in type-III cells. Granulocolor ${ }^{\circledR}$ stained positively type-I, Ia and II cells. General purpose stain Rapidiff® was less vivid than the classical Pappenheim method. The differential count of leukocytes in the peripheral blood of clinically healthy tortoises was determined as follows: $0.372 \pm 0.089$ heterophils, $0.048 \pm 0.011$ eosinophils, 0.051 \pm 0.020 azurophils, $0.050 \pm 0.009$ basophils, $0.467 \pm 0.125$ lymphocytes and $0.012 \pm 0.006$ monocytes. Plasma concentrations of total protein, glucose, uric acid, cholesterol, natrium, potassium, calcium, phosphorus and activities of ALP, ALT, AST were: $45.1 \pm 6.8 \mathrm{~g} / 1,11.4 \pm 1.3$ $\mathrm{mmol} / 1,95.0 \pm 20.1 \mu \mathrm{mol} / 1,4.0 \pm 1.7 \mathrm{mmol} / 1,143.0 \pm 6.5 \mathrm{mmol} / 1,3.8 \pm 0.9 \mathrm{mmol} / 1,2.5 \pm 0.9$ $\mathrm{mmol} / \mathrm{l}, 1.4 \pm 0.4 \mathrm{mmol} / 1$, and $4.5 \pm 2.0 \mu \mathrm{kat} / 1,0.8 \pm 0.4 \mu \mathrm{kat} / 1,1.1 \pm 0.3 \mu \mathrm{kat} / 1$, respectively The differential count of leukocytes and biochemical values may be used as a standard profile for healthy Russian tortoises kept in captivity.

Haematology, Reptilia, Chelonia, Leukocytes

Russian tortoises (Agrionemys horsfieldi, formerly Testudo horsfieldi) are one of the most commonly kept reptiles in Czech Republic. Three different sub-species of Russian tortoise that are distributed throughout Iran, Pakistan, west China, Kazakstan, and Turkmenia can be distinguished. Hundreds of these reptiles are imported into Czech Republic from East Asian countries every year. Among diseases of imported Agrionemys horsfieldi tortoises metabolic disorders prevail, and they are caused by keeping the animals under unsuitable conditions such as high density of animals, low temperature, improper care and inadequate nutrition (Kn otek et al. 2001). Metabolic bone disease, gout and liver diseases are the most frequent diseases. In order to understand better the effect of transport on the health status of tortoises, physiologic indicators of health have to be established based on physical examination along with the evaluation of haematological and clinical biochemical values (Göbel and Spörle 1992; Knotková et al. 2000). Determination of morphologic characteristic of different peripheral blood cells and plasma biochemistry profile of clinically healthy Agrionemys horsfieldi tortoises kept in captivity was the purpose of this study. 


\section{Materials and Methods}

Experimental animals

Twenty adult Russian tortoises (Agrionemys horsfieldi), 13 males and 7 females, clinically healthy and in good condition, were kept at the Department of Reptiles and Small Mammals, Small Animal Clinic, University of Veterinary and Pharmaceutical Sciences Brno. The females were checked by manual examination through cloaca for eggs in oviducts and all of them were determined as non-pregnant. The tortoises were divided into five groups of 4 animals; each group was kept in similar glass-box $(700 \mathrm{~mm} \times 100 \mathrm{~mm} \times 600 \mathrm{~mm})$. The temperature and humidity within all boxes were hold in the range from $20{ }^{\circ} \mathrm{C}$ to $32{ }^{\circ} \mathrm{C}$, and $55 \%$ to $75 \%$, respectively. Dry hay was used as bedding. Tortoises were fed daily green leaves and grass, dandelion, lettuce, Chinese cabbage, cherries, strawberries, tomatoes, oat flakes and cottage cheese ad libitum. Animals were kept under these conditions for 40 days before the start of experiment.

Blood sampling

Tortoises were restrained manually, without sedation. Blood samples for the examination of biochemical as well as haematological profiles were collected from the dorsal coccygeal vein approximately one-third of the tail length from the cloacal opening. The $23 \mathrm{G} \times 1$ Luer needle was inserted at an angle of $30^{\circ}$ to $60^{\circ}$ and advanced until the needle hit the vertebral body. A total of $1 \mathrm{ml}$ of blood was collected from each of the experimental animals.

Blood cell morphology

Blood samples for morphological characterisation of peripheral blood cells were obtained without any anticoagulant. Blood smears were prepared immediately and air-dried. The Pappenheim method (May-Grünwald + Giemsa-Romanowsky staining) for the basal blood cells types characterisation was used. The leukocyte differential counts were assessed by enumeration of 200 cells in each smear stained by the Pappenheim method. Six different commercial staining kits provided by Cytocolor (Cytocolor Inc., Hinckley, Ohio, USA) were used: Rapidiff ${ }^{\circledR}$ - quick, general purpose stain; Lysocolor ${ }^{\circledR}$ - a rapid stain for immature neutrophils; Lymphocolor ${ }^{\circledR}-$ for lymphocytes; Monocolor ${ }^{\circledR}$ - with intense purple reaction in the cytoplasm of monocytes; Granulocolor - stains both primary granules (lysosomes) and secondary granules (specific granules) in all granulocytic cells; Neutrocolor ${ }^{\circledR}$ stains neutrophil granules.

Each cell type was measured and characterized. The stained smears were viewed by the use of the Jenamed 250 CF microscope (Carl Zeiss, Jena, Germany), the images were transformed to digital form by the colour camera 3CCD HV-C20 (Hitachi, Denshi, Japan) and analysed with the supportive program Lucia G (Laboratory Imaging, Prague, Czech Republic).

Plasma biochemistry

The blood from each tortoise was placed into a heparinised tube and centrifuged to yield plasma for the biochemical analyses. Plasma biochemistry parameters were determined on the day of collection. Biochemical assays were performed by use of automated analyzers: the concentration of total protein, glucose, uric acid, cholesterol, phosphorus (P) and activities of alkaline phosphatase (ALP), alanine aminotransferase (ALT), aspartate aminotransferase (AST) were performed on CobasMira analyzer (Roche); plasma concentration of sodium $(\mathrm{Na})$, calcium $(\mathrm{Ca})$ and potassium $(\mathrm{K})$ were performed by Atomspec analyzer (Hilger 1550).

Statistical analyses

Statistical analyses of haematologic and plasma biochemical values were performed using Stat Plus software (Stat Plus, version 1.01, 1990, VUVeL Brno, Czech Republic).

\section{Results}

Blood cell morphology - Pappenheim method

Mature erythrocytes were ellipsoidal cells $(19.5 \pm 1.2 \mu \mathrm{m} \times 9.2 \pm 1.0 \mu \mathrm{m})$ with rounded poles and uniform orange-pink cytoplasm. The nucleus $(6.4 \pm 0.8 \mu \mathrm{m} \times 3.6 \pm$ $0.5 \mu \mathrm{m})$ was elongated with rounded or irregular poles. Its long diameter was parallel with long diameter of the cell. The dense chromatin stained dark purple. Besides these standard form erythrocytes, also other types with more round shape of cell and/or nucleus were observed. They had either the same staining properties (mechanically deformed cells and/or poikilocytosis), or the nucleus was lighter with reticular structure and basophilic cytoplasm - younger cells with more active metabolism (Plate IX, Fig. 1).

Type-V cells (polychromatophil erythrocytes) had regular, smooth, oval shape, $17.2 \pm 0.6$ $\mu \mathrm{m} \times 9.0 \pm 0.5 \mu \mathrm{m}$. The cytoplasm which was blue-violet and very fine-grained, contained 
small vacuoles. The nucleus had pale, large $(13.1 \pm 0.5 \mu \mathrm{m} \times 8.5 \pm 0.5 \mu \mathrm{m})$ and round shape, centrally positioned (Plate X, Fig. 3).

Lymphocytes were $5.7 \pm 0.5 \mu \mathrm{m}$ in diameter. They had compact dark nucleus and thin cytoplasm fringe of blue or violet colour (Fig. 2).

Monocytes, $15.5 \pm 1.5 \mu \mathrm{m}$ in diameter, were cells with large quadratic nuclei with pale and fine chromatin. These cells had square shape, their cytoplasm was blue-gray, spacious, with or without vacuoles.

Type-I cells were routinely designated as heterophils, $13.3 \pm 0.5 \mu \mathrm{m}$ in diameter, with reddish-orange granules in cytoplasm. These granules were spindle - shaped (with sharp poles). However, the shape was not always clearly visible, especially when the cytoplasm was filled with them. The eccentric placed nucleus of heterophil was round to oval (5.9 \pm $0.8 \mu \mathrm{m}$ in diameter), pale blue and darker toward the centre (Fig. 1).

Type-Ia cells (toxic heterophils) were characteristic with round dark inclusions variable in size and count. They can cover the nucleus. The retention of spindle shaped granules was seen (Fig. 3).

Type-II cells (eosinophils) were round cells, slightly larger $(13.5 \pm 0.8 \mu \mathrm{m}$ in diameter) and less numerous than type-I cells. Their granules were darker, more red and round. Nucleus $(8.6 \pm 1.5 \mu \mathrm{m} \times 5.7 \pm 0.6 \mu \mathrm{m})$ was eccentric placed, uniform in colour, with clumped chromatin (Fig. 1).

Type-III cells (azurophils), $9.7 \pm 1.0 \mu \mathrm{m}$ in diameter, contained large nucleus ( $8.8 \pm 1.0$ $\mu \mathrm{m} \times 6.0 \pm 0.3 \mu \mathrm{m})$, usually slightly indented or having hemispheric character. The chromatin was dark purple, coarsely clumped. Pink granules in clutches or clouds were seen in blue-grey smoky cytoplasm (Fig. 1).

The cytoplasm of type-IV cells (basophils) was filled with round granules, which are large, prominent over periphery. Colour varied from deep purple to deep blue or black. These cells were $9.5 \pm 0.6 \mu \mathrm{m}$ in diameter. The nucleus was almost invisible, only chromatin clumps were observed (Fig. 2).

The nucleus of thrombocytes was round to oval and dark. The cytoplasm of one form of thrombocytes was find sitting on the nucleus, or instead of that the membrane loosely frilled around the nucleus. The other form was oval with a good visible membrane and transparent cytoplasm (Fig. 2, Fig. 3).

Blood cell morphology - Cytocolor staining

Rapidiff ${ }^{\oplus}$ : erythrocytes had dark violet nucleus and blue cytoplasm. The type-I cells had smoky cytoplasm showing spaces where the unstained spine-shaped granules should be situated. The Ia form cells had the round inclusions with red-brown reaction. The type-II cells had round granules which stain outstanding turquoise blue. Remaining blood cells stained comparable as with classic Pappenheim method, but the colours were less vivid.

Lysocolor ${ }^{\circledR}$ : in the cytoplasm of Ia and IV cells positive black reaction was present. The fine reticular structure was seen in the cytoplasm of type-III cells. Only nucleus stained in the remaining cells (Plate X, Fig. 4).

Lymphocolor ${ }^{\circledR}$ : using of this kit blood cells lighted brightly yellow under dark-field illumination.

Monocolor ${ }^{\circledR}$ : nuclei of blood cells stained deeply violet, the colour of cytoplasm was smoky violet, cytoplasm was blue in erythrocytes. Granules of type-I cells did not stain, granules of type-II cells were brightly blue (Fig. 4).

Granulocolor ${ }^{\circledR}$ : granules in cytoplasm of type-I and type-II cells were intensely red. The distinguishing characteristic between these granulocytes was the shape of the granules.

Neutrocolor ${ }^{\circledR}$ : unclear blue shadows were present in cytoplasm, and fine red dots were spread all over cells. Nucleus did not stain. 
The leukogram

The differential lekocyte count in the peripheral blood is reviewed in Table 1.

Table 1

Differential leukocyte count in the peripheral blood of Russian tortoises (Agrionemys horsfieldi)

\begin{tabular}{|l|c|c|c|c|c|c|}
\hline & Heterophils & Eosinophils & Azurophils & Basophils & Lymphocytes & Monocytes \\
\hline $\min$ & 0.130 & 0.020 & 0.033 & 0.020 & 0.361 & 0.001 \\
\hline $\max$ & 0.456 & 0.059 & 0.120 & 0.076 & 0.756 & 0.021 \\
\hline Mean & 0.372 & 0.048 & 0.051 & 0.050 & 0.467 & 0.012 \\
\pm SD & 0.089 & 0.011 & 0.020 & 0.009 & 0.125 & 0.006 \\
\hline
\end{tabular}

Plasma biochemistry

Results of plasma biochemistry analyses are summarised in Table 2.

Table 2

Blood biochemistry values obtained from healthy Russian tortoises (Agrionemys horsfieldi)

\begin{tabular}{|l|c|c|c|c|}
\hline \multirow{2}{*}{ Parameter } & \multicolumn{3}{c|}{ Healthy tortoises $(\mathrm{n}=20)$} \\
\cline { 3 - 5 } & $\mathrm{g} / \mathrm{l}$ & $\mathrm{min}$ & max. & Mean \pm SD \\
\hline Total protein & $\mathrm{mmol} / \mathrm{l}$ & 8.9 & 68.5 & $45.1 \pm 6.8$ \\
\hline Glucose & $\mu \mathrm{mol} / \mathrm{l}$ & 37.6 & 12.0 & $11.4 \pm 1.3$ \\
\hline Uric acid & $\mu \mathrm{kat} / \mathrm{l}$ & 1.8 & 150.0 & $95.0 \pm 20.1$ \\
\hline ALP & $\mu \mathrm{kat} / \mathrm{l}$ & 0.5 & 7.2 & $4.5 \pm 2.0$ \\
\hline ALT & $\mu \mathrm{kat} / \mathrm{l}$ & 0.5 & 1.2 & $0.8 \pm 0.4$ \\
\hline AST & $\mathrm{mmol} / \mathrm{l}$ & 3.0 & 6.5 & $1.1 \pm 0.3$ \\
\hline Cholesterol & $\mathrm{mmol} / \mathrm{l}$ & 139.0 & 145.0 & $4.0 \pm 1.7$ \\
\hline $\mathrm{Na}$ & $\mathrm{mmol} / \mathrm{l}$ & 2.0 & 4.2 & $143.0 \pm 6.5$ \\
\hline $\mathrm{K}$ & $\mathrm{mmol} / \mathrm{l}$ & 1.7 & 2.9 & $3.8 \pm 0.9$ \\
\hline $\mathrm{Ca}$ & $\mathrm{mmol} / \mathrm{l}$ & 0.7 & 1.9 & $2.5 \pm 0.9$ \\
\hline $\mathrm{P}$ & & & $1.4 \pm 0.4$ \\
\hline
\end{tabular}

\section{Discussion}

Reptiles are a heterogenous group of vertebrates with regard to their blood cell morphology. Because the differential blood cell count is important in determining the health status of animals, normal blood morphology needs to be described for representative species of the 4 major orders of reptiles.

All blood smears in the present study were prepared immediately after venipuncture from native blood, to prevent any possible influence of anticoagulant on cell morphology. Blood exposed to heparin for several hours will usually not stain as well as slides made immediately after collection (W alberg 2001). Haemolytic destruction of chelonian cells by EDTA was described (Mc Arthur 1996; Muro et al. 1998). EDTA is widely used in avian practice, however, it is reported to cause hemolysis of blood in some avian species (W alberg 2001). We had the same experience with blood collected from tortoises Geochelone gigantea and Geochelone elephantopus (unpublished data).

Reptilian peripheral blood cells can be basically termed as erythrocytes, leukocytes and thrombocytes. Erythrocytes are morphologically similar among various species of reptiles (Saint Girons 1970). Erythrocyte nuclei become more condensed and stain darker as the cells age. Basophilic cytoplasm in polychromatic erythrocyte is sign of its immaturity. The nucleus is centrally positioned. We consider the type- $\mathrm{V}$ cell to be a stage of polychromatophil erythrocyte. Based on our experience, such cell type is not very common 
in the peripheral blood of tortoises or other reptile species. We can observe round forms of the erythrocyte precursors, dark blue cells with deep purple nuclei and coarse-grain chromatin. Garner et al. (1996) remind of opinion, that reptilian erythrocytes may arise from up to 5 types of stem cells.

Nucleus in mature erythrocyte is round in Gopherus tortoises (Alleman et al. 1992; Garner et al. 1996) as well as in green turtles (Samour et al. 1998; Work et al. 1998). We have the same experience with red eared sliders (Trachemys scripta). Thus long and/or irregular shape of Agrionemys horsfieldi erythrocytes resemble more erythrocytes from snakes (Alleman et al. 1999).

The classification of reptilian leukocytes poses many problems, partly because these cells show morphological variation within the class and partly because several different nomenclatures have been used to describe them. Some of the leukocyte types occurring in reptiles closely resemble those of mammals and birds and, by analogy, lymphocytes, monocytes and basophils can be classified as such in all mammals, birds and reptiles. However, the status in reptiles of the acidophilic granulocytes and the unique azurophils is more difficult to elucidate. For example Saint Girons (1970) reported the presence of eosinophils, azurophils, neutrophils and plasma cells in reptiles, Sy pek and Borysenko (1988) described eosinophils and heterophils in reptilian blood. Wood and Ebanks (1984) described eosinophils and neutrophils. Widely accepted opinion is that reptilian (Montali 1988) and avian heterophils (Brooks et al. 1996) have functions similar to mammalian neutrophils. The presence of eosinophils vary among various species of reptiles. Pienaar (1962) reported about heterophils and eosinophils as about type-1 and type-2 eosinophils. Saint Girons (1970) considered these cells as morphological variants of a single cell line. The evidence exists, that these acidophils are each derived from separate lines (Mateo et al. 1984). Eosinophils are present in chelonians as well as in crocodilians. Only heterophils were recognized in most squamates. Reptilian azurophils are described with morphologic features of monocytes and acidophils (Alleman et al. 1992). The metachromatic reaction of their cytoplasm could be used to distinguish them from monocytes (Hawkey and Dennet 1989).

Two types of thrombocytes were present in Agrionemys horsfieldi tortoises: the oval with a good visible membrane and transparent cytoplasm, and the rectangular with small projections of lightly basophilic cytoplasm. The similarity of thrombocytes and lymphocytes in reptiles is known (Saint Girons 1970; Frye 1991). The oval form with transparent cytoplasm was not formed in gopherus tortoise (Alleman et al. 1992; Garner et al. 1996), however, it was described in green turtles (Work et al. 1998) and American alligator (Alligator mississipiensis, Mateo et al. 1984). We found both of these forms in Agrionemys horsfieldi tortoises. This variability could be a product of ageing, function or artifact. Garner et al. (1996) suggested that several sources of thrombocytes could exist.

Cells known as heterophils and eosinophils (sometime designated as acidophils) are believed to be present in chelonians (Allem an et al. 1992). The main difference is the shape of granules. Sometimes it is difficult to distinguish the type of granules with the basic Pappenheim's smears, because the cytoplasm is filled with them. Granulocolor ${ }^{\circledR}$ is more exact. We suggest that Granulocolor ${ }^{\circledR}$ would be appreciated in cases of special importance. Pappenheim method is sufficient for routine laboratory examination of tortoisehemogram.

The main problem with acidophils is whether these cell types present only two different types of single line cell development, or are they really two independent cells? Garner et al. (1996) found both in the bone marrow of Gopherus agassizii. Using Rapidiff ${ }^{\circledR}$ the granules of type-II accepted the stain, unlike type-I granules did not. So called toxic changes in type-Ia were seen, and retention of spindle-shape granules document its relation to type- 
I cell. Toxic granules stained positively with Lysocolor. No similar effect in type-II cell was seen. The interesting finding was the single lobed nucleus in type-I cell (heterophil). Chelonian's heterophils nuclei are commonly unlobed. Blofield et al. (1992) suggested either evolutionary relation of nuclear lobulation, or result of ageing the cells if need for them in the body is elevated. Based on this knowledge, we support the opinion that type-I and type-II are two different cells.

Information is lacking about the origin of azurophils and these cells have been variously considered as allied to the granulocyte or monocyte series. Alleman et al. (1992) as well as Garner et al. (1996) described this cell type in Gopher tortoises as to be azurophil monocyte. Samour et al. (1998) described azurophils in green turtle. Work et al. (1998) found no similar cell in the same species. Cells of such type are classified as monocyte line in birds. In the present study, we have found the "classic" type of monocytes only in one sample. However, Cytocolor ${ }^{\circledR}$ kits brought no additional light into this problem. Unfortunately, monocytes were too rare to tell if they stain positively by Monocolor ${ }^{\circledR}$. This kit showed no reaction typical for mammalian monocyte in any other cell. Lysocolor stained black reticular structure in the cytoplasm of type-III cells. It showed no expected reaction as neutrophils. Cytochemical characteristics of monocytes and azurophils differ among various species of reptiles (Mateo et al. 1984, Work et al. 1998, Alleman et al. 1999, Harr et al. 2001).

Basophils were more commonly observed in tortoise blood than in mammalian blood. In the present study type-IV cells surprisingly stained with Lysocolor ${ }^{\circledR}$. This is not typical of mammalian basophils.

As far as concerns Cytocolor ${ }^{\circledR}$, we found Rapidiff ${ }^{\circledR}$ to be not so illustrative for routine laboratory work as Pappenheim method. It is good for distinguishing type-I and type-II cells. Lysocolor ${ }^{\circledR}$ was excellent for the detection of lysosomes. It gave positive reaction in type-Ia and IV cells in Agrionemys horsfieldi. Monocolor ${ }^{\circledR}$ showed no reaction, further investigation is need. Lymphocolor ${ }^{\circledR}$ and Neutrocolor ${ }^{\circledR}$ brought no contribution to our knowledge.

Plasma biochemistry profile in reptiles involves analysis of well separated heparinised plasma for the concentrations of total protein, glucose, uric acid, cholesterol, calcium, phosphorus, sodium, potassium and activities of alkaline phosphatase, alanine aminotransferase and aspartate aminotransferase (Jacobson 1992). The activities of blood urea nitrogen and creatinine in reptilian plasma are considered to be of low practical importance for monitoring liver and/or renal physiology (Divers et al. 1996). There are at least two reasons for this argument. At first, most reptiles belong to uricotelic vertebrates. The second reason is that reptilian patients with renal disease often have normal urea and creatinine values. The concentration of uric acid seems to be the most reliable indicator of renal disease in reptiles (Divers et al. 1996). Hypoglycaemia, hyperuricaemia and hyperphosphataemia reflect serious changes in the hepatic and renal function of Hermann's tortoises as well as Russian tortoises or giant tortoises with clinical signs of wasting syndrome (S a mour et al. 1986; Göbel and S pörle 1992; Knotková et al. 2000; Knotek et al. 2001). The plasma levels of uric acid in Russian tortoises from this study are in the normal range for tortoises, as has been published (Mc Arthur 1996; Knotek et al. 1999; Knotek et al. 2001; Kölle and Hoffmann 2001). The increase of uric acid may indicate renal damage in tortoises (Kölle and Hoffmann 2001). However, uric acid levels do not increase significantly until the extensive damage of kidney (Miller 1998). Hyperphosphataemia which is not of postprandial origin, seems to be a reliable indicator of renal insufficiency in reptiles (Miller 1998). Elevation in serum or plasma phosphorus level is often associated with renal failure. Indeed, the phosphorus-calcium ratio could be a sensitive parameter for the diagnosis of early stage of renal disease (Kölle and Hofmann 2001). 
The diagnosis of different forms of liver diseases in reptiles is very difficult and a complex of diagnostic steps is essential. The preference for intravital diagnosis challenge the clinician to combine different methods. Plasma biochemistry assays are compared with methods of diagnostic imaging and histopathologic examinations of tissue samples obtained by liver biopsy (Divers and Cooper 2000). The plasma activities of ALP, ALT and AST can all rise during liver disease, aspartate aminotransferase elevation seems to be of clinical importance (Divers et al. 1996; Divers and Cooper 2000), too. The plasma activities of ALP, ALT, AST and concentration of cholesterol in tortoises from this study are all in the normal range for healthy Russian tortoises, as have been published previously (Kn otek et al. 1999; Knotek et al. 2001).

The values for $\mathrm{Na}, \mathrm{K}, \mathrm{Ca}$ and $\mathrm{P}$, respectively, were also similar to results recently published for a group of imported healthy Russian tortoises. We have not seen any sexdependent differences in blood biochemistry profile for healthy Russian tortoises in our previous study (Knotek et al. 2001). Indeed, there were only adult males and females used for the present study. Moreover, all females were checked manually through cloaca and found non-pregnant.

We suggest that the biochemical profile described in the present study may be used as a standard profile for healthy Russian tortoises kept in captivity. Nevertheless, some differences especially for young tortoises with rapid growth and/or for adult females during the reproductive season could be expected.

\section{Morfologie buněčných krevních elementů a biochemický profil krevní plazmy želv stepních (Agrionemys horsfieldi)}

Ve vzorcích periferní krve 20 zdravých želv stepních (Agrionemys horsfieldi) byla studována morfologická charakteristika buněčných elementů a v krevní plazmě byly stanoveny vybrané biochemické parametry. Pro obarvení krevních nátěrů byly použity přehledné metody dle Pappenheima a setem Rapidiff ${ }^{\circledR}$ a selektivní barvení komerčními sety Lysocolor $^{\circledR}$, Lymphocolor ${ }^{\circledR}$, Monocolor ${ }^{\circledR}$, Granulocolor ${ }^{\circledR}$ a Neutrocolor ${ }^{\circledR}$. Bylo popsáno 10 typů krevních buněk: erytrocyty, trombocyty, lymfocyty, monocyty, heterofilní granulocyty, eozinofilní granulocyty, bazofilní granulocyty, toxické heterofilní granulocyty, azurofily a polychromatofilní erytrocyty. Lysocolor ${ }^{\circledR}$ barvil granula bazofilů a méně výrazně azurofilů. Granulocolor ${ }^{\circledR}$ barvil granula heterofilů, toxických heterofilů a eozinofilů. Přehledné barvení setem Rapidiff ${ }^{\circledR}$ bylo méně výrazné než využití klasické Pappenheimovy metody. Diferenciální rozpočet leukocytů měl lymfocytární charakter: lymfocyty $0.467 \pm 0.125$, monocyty $0.012 \pm 0.006$, heterofily $0.372 \pm 0.089$, eozinofily $0.048 \pm 0.011$, bazofily $0.050 \pm 0.009$, azurofily $0.051 \pm 0.020$. Koncentrace celkové bílkoviny, glukózy, kyseliny močové, cholesterolu, sodíku, draslíku, vápníku, fosforu a aktivity ALP, ALT, AST v krevní plazmě byly následující: $45.1 \pm 6.8 \mathrm{~g} / 1,11.4 \pm 1.3 \mathrm{mmol} / \mathrm{l}$, $95.0 \pm 20.1 \mu \mathrm{mol} / \mathrm{l}, 4.0 \pm 1.7 \mathrm{mmol} / \mathrm{l}, 143.0 \pm 6.5 \mathrm{mmol} / \mathrm{l}, 3.8 \pm 0.9 \mathrm{mmol} / 1,2.5 \pm 0.9 \mathrm{mmol} / \mathrm{l}$, $1.4 \pm 0.4 \mathrm{mmol} / \mathrm{l}$ a $4.5 \pm 2.0 \mu \mathrm{kat} / 1,0.8 \pm 0.4 \mu \mathrm{kat} / 1,1.1 \pm 0.3 \mu \mathrm{kat} / \mathrm{l}$. Diferenciální rozpočet leukocytů a stanovené biochemické parametry zdravých želv Agrionemys horsfieldi chovaných v zajetí budou využity v klinické patologii plazů.

\section{Acknowledgements}

This project was supported by the grant of the Ministry of Education, Youth and Physical Education of the Czech Republic (No. 161700002).

\section{References}

ALLEMAN, AR, JACOBSON, ER, RASKIN, RE 1992: Morphologic and cytochemical characteristics of blood cells from the desert tortoise (Gopherus agassizii). Am J Vet Res 53: 1645-1651

ALLEMAN, AR, JACOBSON, ER, RASKIN, RE 1999: Morphologic, cytochemical staining, and ultrastructural 
characteristics of blood cells from eastern diamondback rattlesnakes (Crotalus adamanteus). Am J Vet Res 53: 1645-1651

BLOFIELD, BA, SHORT, L, SAMOUR, HJ, BALL, D, HAWKEY, CM 1992: Phylogenetic and haematological implications of differences in the morphology of the heterophil nucleus in reptiles. J Zool Lond 226: 539-549

BROOKS, RL jr, BOUNOUS, DI, ANDREASEN, CB 1996: Functional comparison of avian heterophils with human and canine neutrophils. Comp Haematol Int 6: 153-159

DIVERS, SJ, COOPER, JE 2000: Reptile hepatic lipidosis. Semin Avian Exotic Pet Med 9: 153-164

DIVERS, SJ, REDMAYNE, G, AVES, EK 1996: Haematological and biochemical values of 10 green iguanas (Iguana iguana). Vet Record 138: 203-205

FRYE, FL 1991: Hematology as applied to clinical reptile medicine. In: Reptile Care. An Atlas of Diseases and Treatment. TFH Publications Inc., Neptune City, New Jersey, pp. 211-277

GARNER, MM, HOMER, BL, JACOBSON, ER, RASKIN, RE, HALL, BJ, WEIS, WA, BERRY, KH 1996: Staining and morphologic features of bone marrow hematopoietic cells in desert tortoises (Gopherus agassizii). Am J Vet Res 57: 1608-1615

GÖBEL, T, SPÖRLE, H 1992: Blutentnahmetechnik und Serumnormalwerte wichtiger Parameter bei der Griechischen Lanschildkröte (Testudo hermanni hermanni). Tierärztl Prax 20: 231-234

HARR, KE, ALLEMAN, AR, DENNIS, PM, MAXWELL, LK, LOCK, BA, BENNETT, RA, JACOBSON, ER 2001: Morphologic and cytochemical characteristics of blood cells and hematologic and plasma biochemical reference ranges in green iguanas. J Am Vet Med Assoc 218: 915-921

HAWKEY, CM, DENNETT, TB 1989: A Colour Atlas of Comparative Veterinary Haematology. Wolfe Medical Publications Ltd, Ipswich, 192 p.

JACOBSON, ER 1992: Laboratory investigations. In: BEYNON, PH, LAWTON, MPC, COOPER, JE Manual of reptiles. BSAVA, Cheltenham, pp. 49-62

KNOTEK, Z, HAUPTMAN, K, KNOTKOVÁ, Z, ŠEBESTA, R 2001: The health status of Agrionemys horsfieldi tortoises imported to Czech Republic. Proc 40 ${ }^{\text {th }}$ Symp. Dis Zoo Wild Anim, 23. - 26. 5. Rotterdam, 57-59

KNOTEK, Z, KNOTKOVÁ, Z, HALOUZKA, R, MODRY, D, HÁJKOVÁ, P 1999: Nemoci plazů. ČAVLMZ, Brno, $275 \mathrm{p}$.

KNOTKOVÁ, Z, KNOTEK, Z, HÁJKOVÁ, P 2000: Plasma biochemistry of chelonians of the Geochelone group. Proc. $3^{\text {rd }}$ EAZWV Sci Meeting, 31.5. - 4.6. Paris, 281-285

KÖLLE, P, HOFFMANN, R 2001: Renal diseases in reptiles: diagnostic tools. Proc. $40^{\text {th }}$ Symp Dis Zoo Wild Anim, 23. - 26. 5. Rotterdam, 67-69

MATEO, MR, ROBERTS, ED, ENRIGHT, FM 1984: Morphologic, cytochemical, and functional studies of peripheral blood cells of young healthy American alligators (Alligator mississippiensis). Am J Vet Res 45: 10461053

McARTHUR, S 1996: Veterinary management of tortoises and turtles. Blackwell Science, Oxford, $170 \mathrm{p}$.

MILLER, HA 1998: Urinary diseases of reptiles. Semin Avian Exotic Pet Med 7: 93 - 103

MONTALI, RJ 1988: Comparative pathology of inflammation in the higher vertebrates (reptiles, birds and mammals. J Comp Pathol 99: 1-26

MURO, J, CUENCA, R, PASTOR, J, VINAS, L, LAVIN, S 1998: Effects of lithium heparin and tripotassium EDTA on hematologic values of Hermannęs tortoises (Testudo hermanni). J Zoo Wildl Med 29: 40-44

PIENAAR, UV 1962: Haematology of some South African reptiles. Witwatersrand University Press, Johannesburg, 27-33

SAINT GIRONS, MC 1970: In: Gans C (Ed) Biology of the Reptilia. Vol 3., Academic Press Inc. New York, pp. 91

SAMOUR, JH, HAWKEY, CM, PUGSLEY, S, BALL, D 1986: Clinical and pathological findings related to malnutrition and husbandry in captive giant tortoises (Geochelone species). Vet Record 118: 299 - 302

SAMOUR, H, HOWLETT, JC, SILVANOSE, C, HASBUN, CR, Al-GHAIS, SM 1998: Normal haematology of free-living green sea turtles (Chelonia mydas) from the United Arab Emirates. Comp Haematol Int 8: 102-107

SYPEK, J, BORYSENKO, M 1988: In: Rowley, AF and Ratcliffe, NA (Eds) Vertebrate blood cells. Cambridge University Press, Cambridge, pp. 211-256

WALBERG J 2001: White blood cell counting techniques in birds. Semin Avian Exotic Pet Med 10: $72-76$

WOOD, FE, EBANKS, GK 1984: Blood cytology and hematology of the green sea turtle, Chelonia mydas. Herpetologica 40: $331-336$

WORK, TM, RASKIN, RE, BALASZ, GH, WHITTAKER, SD 1998: Morphologic and cytochemical characteristics of blood cells from Hawaiian green turtles. Amer J Vet Res 59: 1252-1257 
Plate IX

Knotková Z. et al.: Blood Cell... pp. 193-198
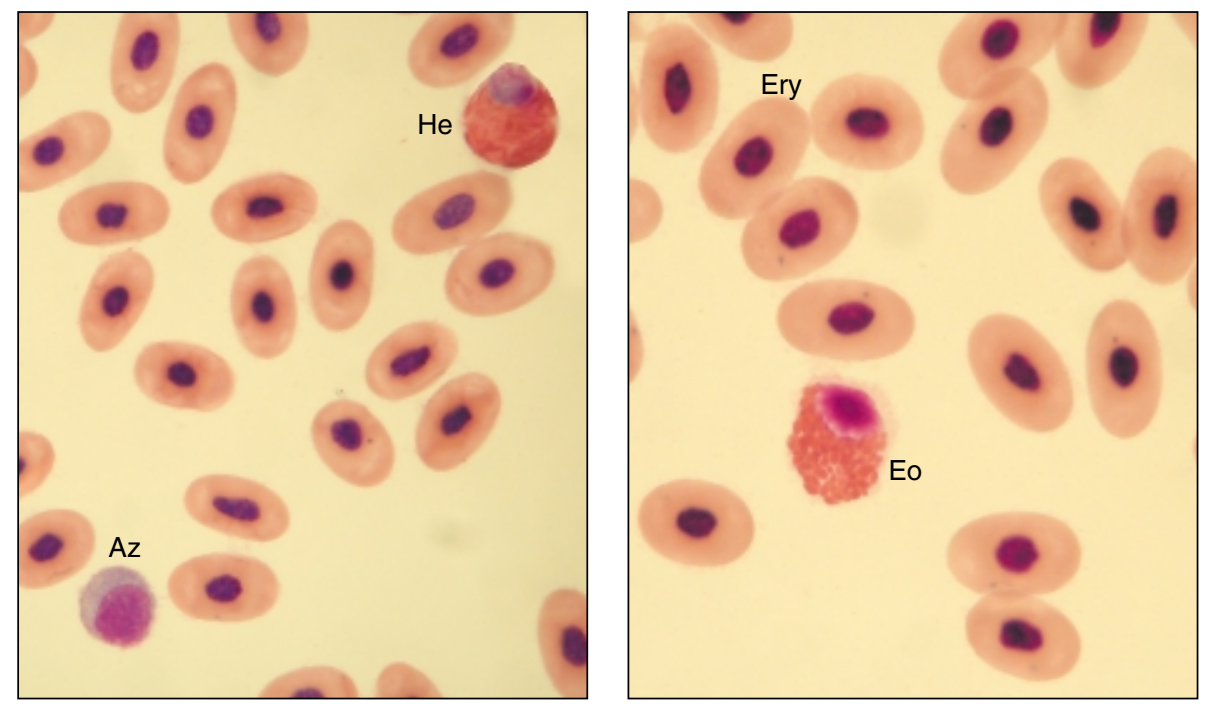

Fig. 1 Agrionemys horsfieldi. He - heterophil, Az - azurophil, Eo - eosinophil, Ery - erythrocytes. Pappenheim staining method, $\times 1000$.
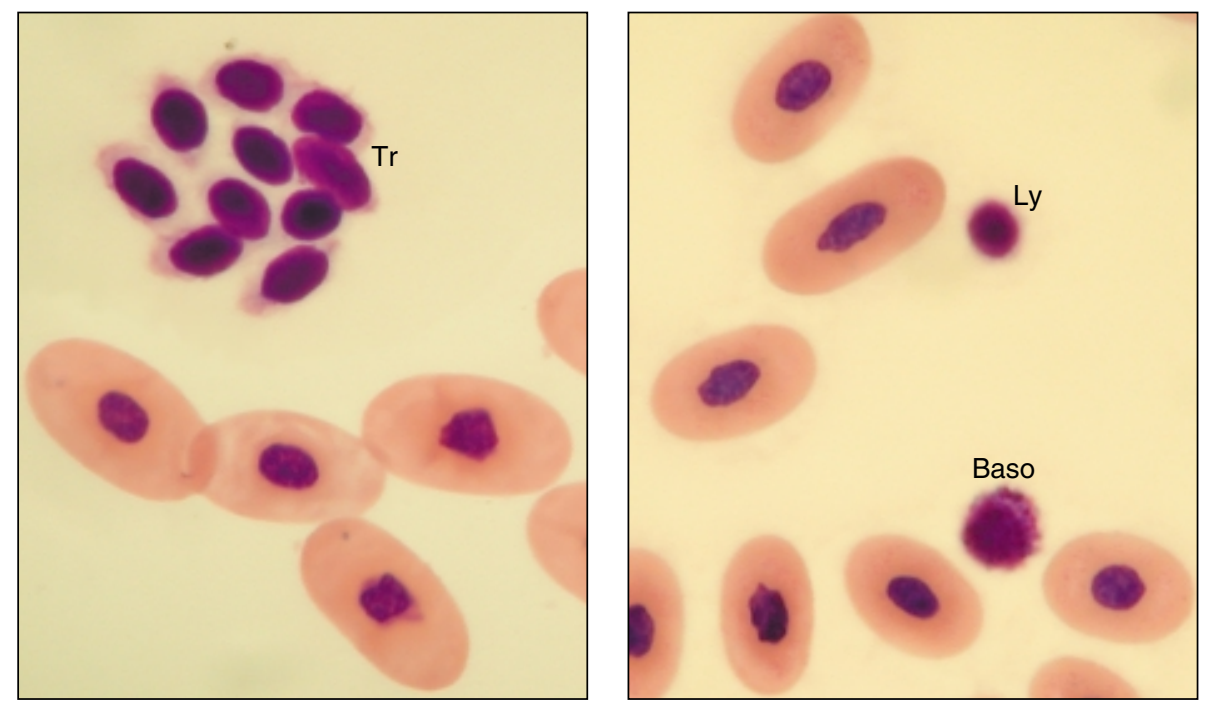

Fig. 2 Agrionemys horsfieldi. $\mathrm{Tr}$ - thrombocytes, Ly - lymphocyte, Baso - basophil. Pappenheim staining method, $\times 1000$. 
Plate X
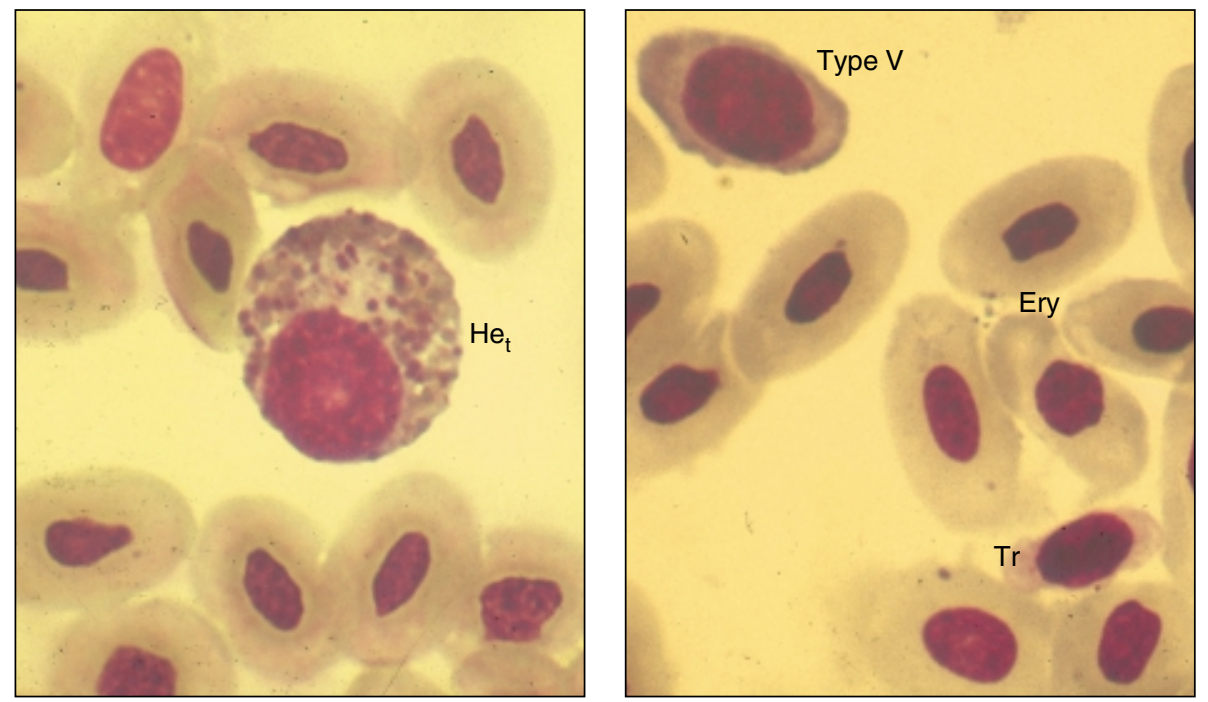

Fig. 3 Agrionemys horsfieldi. $\mathrm{He}_{\mathrm{t}}$ - toxic heterophil, Ery - erythrocytes, Type V - polychromatophil erythrocyte, $\mathrm{Tr}-$ thrombocyte. Pappenheim staining method $\times 1000$.
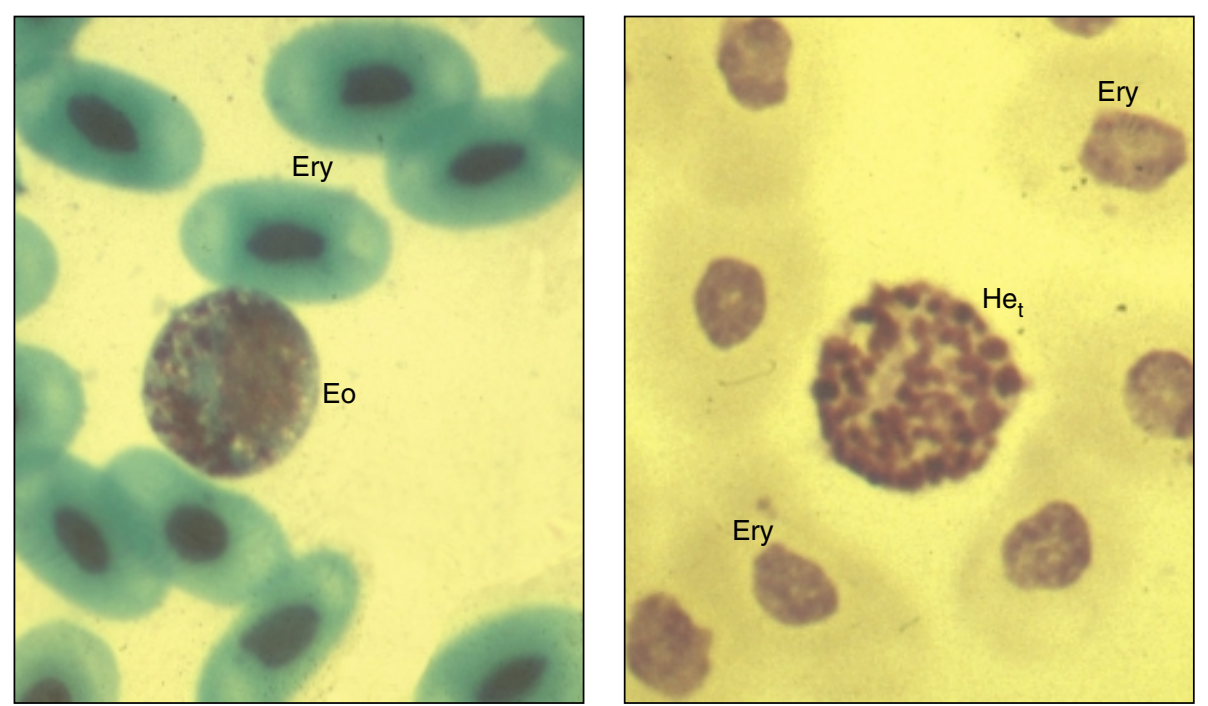

Fig. 4 Agrionemys horsfieldi. Eo - eosinophil, Ery - erythrocytes (Monocolor ${ }^{\circledR}$ staining method). $\mathrm{He}_{\mathrm{t}}$ - toxic heterophil, Ery - erythrocytes (Lysocolor staining method), $\times 1000$. 